\title{
Evaluation of the nutritive value of yellow rice in rats and broiler chicks
}

\author{
BY S. PANIGRAHI, S. PHILLIPS, V. E. PLUMB AND A. J. WATSON \\ Natural Resources Institute, Chatham Maritime, Central Avenue, Chatham, Kent ME4 4TB
}

(Received 8 July 1991 - Accepted 17 December 1991)

\begin{abstract}
Yellow discoloration often develops in rice kernels during post-harvest storage, due possibly to fungal activity. The present study examined the changes in nutrient composition taking place during yellowing of rice, and the effects of feeding rats and broiler chicks on a moderately yellow rice at $600 \mathrm{~g} / \mathrm{kg}$ diet. Nitrogen content was found to be higher in rice grains that had become more yellow, only part of the increase being in non-protein- $\mathrm{N}$; however, relative to crude protein $(\mathrm{N} \times 6.25)$ the concentrations of lysine, methionine, cystine and arginine were lower. There were no significant differences between white and yellow rice in the food intake, weight gain and efficiency of food utilization (EFU) of rats and chicks when diets were formulated to contain similar nutrient concentrations, or the same basal ingredient composition. Diet pelleting increased food intake and weight gain in both animal species, but reduced dry matter and energy digestibility in rats; effects on nutrient retention in chicks were largely non-significant. Liver weights of rats and chicks and pancreas weights of chicks were unaffected by yellow rice; however, chicks fed on mash had a larger pancreas on average than those fed on pellets. Thus, whilst the nutrient composition of rice is altered during yellowing, a moderately yellow rice is unlikely to produce major adverse effects when fed to rats and broiler chicks.
\end{abstract}

Yellow rice: Toxicity: Nutritive value: Rats: Broiler chicks

Yellow discoloration of rice grains during post-harvest drying and storage (sometimes termed stack-burnt rice) is a common problem in tropical countries which reduces the acceptability of the rice and results in its down-grading for human consumption, with consequent economic losses to the farmer. Rice yellowing has been associated with the growth of specific fungi (Van der Wolk, 1913), and may be caused by an increase in the temperature of the rice stack resulting from the heat of metabolism of fungi (International Rice Research Institute, 1983). Several fungi belonging to the genera Aspergillus and Penicillium, and others including Humicola lanuginosa and Corynascus sepedonium, have been isolated from yellow rice (Phillips et al. 1988, 1989). Gras et al. (1989) reported that yellowing can also occur in rice that is stored under optimum conditions. It is now believed that the discoloration is due to a non-enzymic browning reaction between the reducing groups of sugars and free amino groups of proteins, with fungal infection of the grain increasing the concentrations of these groups by amylolytic and proteolytic activities, thereby accelerating the browning of the kernels (D. R. Twiddy and S. I. Phillips, personal communication).

There is limited information in the literature concerning the effects of feeding yellow rice to animals, and it is not clear whether yellowing is associated with a loss in nutritive value or in the production of toxins. There are some reports of a correlation between liver lesions (Kinosita \& Shikata, 1965; Moreau, 1979), including cirrhosis (Saito, 1959), and the consumption of a yellow rice that had become mouldy with Penicillium islandicum. Yellow rice is reported to contain a lower concentration of lysine than white rice (Eggum et al. 
1984), and may, therefore, be regarded as having a lower nutritive value. However, Noland et al. (1969) reported that yellow rice could replace half the maize in the diets of growing and finishing pigs without any adverse effects on growth or on meat quality.

The present study was undertaken to examine the effects of yellowing on the nutrient composition and the nutritional and toxicological characteristics of rice. Feeding trials were carried out with $(a)$ rats as a model for humans, in view of the importance of rice as a staple human food, and $(b)$ broiler chicks to determine the potential for use of such down-graded rice in non-ruminant diets. As there was some uncertainty about the ability of rats and young chicks to consume mash feeds containing whole rice, and the possibility that pelleting could affect normal and yellow rice differently, experiments were based on a $2 \times 2$ factorial design that also studied the effects of diet pelleting.

\section{EXPERIMENTAL METHODS \\ Composition of the rice}

Samples $(70 \mathrm{~kg}$ ) of milled white and yellow rice were obtained from the International Rice Research Institute in the Philippines. The yellow rice sample was separated into four grades of yellow to determine whether any systematic change in nutrient composition had occurred during the yellowing process. The sample, graded visually, comprised $(\mathrm{g} / \mathrm{kg}): 149$ white (normal), 502 slightly yellow, 278 moderately yellow or light brown, 71 very yellow (almost brown) rice. The white rice sample comprised $(\mathrm{g} / \mathrm{kg}): 992$ normal, 8 slightly-tomoderately yellow rice.

The proximate compositions of rice were determined according to the methods recommended by the Ministry of Agriculture, Fisheries and Food (1986), the amino acid composition of hydrochloric acid-hydrolysed dried and defatted samples was determined using a Biotronik Amino acid LC5000 analyser, and gross energy values using a Gallenkamp adiabatic bomb calorimeter (Tables 1 and 2). Non-protein-nitrogen determinations were carried out according to Backhoff (1976), using $20 \mathrm{ml}$ trichloroacetic acid and centrifuging the homogenized material before filtration to prevent the rice starch clogging up the filter paper.

\section{Feeding trials}

Two approaches were adopted in studying the effects of including yellow rice in the diets of rats and chicks: the first examined whether the feeding of yellow rice produced any shortterm toxic effects (Expts 1 and 2) using diets balanced for nutrients, and the second compared the nutritive value of yellow rice with that of the control white rice by substitution in a basal diet (Expt 3).

\section{Expt 1}

White and yellow rice were incorporated at $600 \mathrm{~g} / \mathrm{kg}$ in rat diets of similar proximate, lysine, and methionine plus cystine contents, based on the analysis of each rice. To facilitate the detection of any differences existing in the feeding value of the two rice types, dietary crude protein, lysine and methionine plus cystine were kept at concentrations submaximal to the requirements of rats. Pelleting was carried out with the addition of $50 \mathrm{~g}$ water $/ \mathrm{kg}$ in a Lister pelleter equipped with a $3.5 \mathrm{~mm}$ die head. The experimental diets were: white-rice mash, yellow-rice mash, white-rice pellets, yellow-rice pellets and commercial pellets $(8 \mathrm{~mm}$ diameter, Beekay Rat and Mouse autoclavable diet obtained from Bantin and Kingman, UK, Ltd) (CON). The composition and proximate analyses of diets are shown in Table 3.

Sixty male Wistar rats (Sprague-Dawley), weighing 60-80 g, were obtained from Bantin and Kingman UK Ltd. They were housed in groups of three in plastic cages arranged in five 
Table 1. Composition of the white (normal) and yellow milled rice samples $(\mathrm{g} / \mathrm{kg}$ unless otherwise stated)

\begin{tabular}{|c|c|c|}
\hline & White rice & Yellow rice \\
\hline Moisture & $119 \cdot 7$ & 110.9 \\
\hline \multicolumn{3}{|l|}{ Crude protein (nitrogen $\times 6.25$ ): } \\
\hline Mean & $82 \cdot 9$ & $87 \cdot 0$ \\
\hline $\mathrm{SE}$ & 0.65 & 0.89 \\
\hline Crude fat & $7 \cdot 1$ & $3 \cdot 7$ \\
\hline Crude fibre & $4 \cdot 6$ & $4 \cdot 8$ \\
\hline Ash & $5 \cdot 3$ & 4.9 \\
\hline Calcium & 0.05 & 0.07 \\
\hline Phosphorus & $1 \cdot 1$ & $1 \cdot 0$ \\
\hline Starch* & $743 \cdot 0$ & $736 \cdot 0$ \\
\hline Available starch and sugars $\dagger$ & $763 \cdot 0$ & $744 \cdot 0$ \\
\hline Sugars & $10 \cdot 5$ & 11.6 \\
\hline Sugars $\S$ & $<15$ & $<15$ \\
\hline \multicolumn{3}{|l|}{ Gross energy: } \\
\hline$(\mathrm{MJ} / \mathrm{kg})$ & $15 \cdot 83$ & $15 \cdot 86$ \\
\hline$(\mathrm{MJ} / \mathrm{kg} \mathrm{DM})$ & $17 \cdot 69$ & $17 \cdot 62$ \\
\hline Nitrogen (dried and defatted) & $13 \cdot 7$ & $14 \cdot 5$ \\
\hline \multicolumn{3}{|l|}{ Amino acids $(\mathrm{g} / 16 \mathrm{~g} \mathrm{~N})$} \\
\hline Aspartic acid & $9 \cdot 83$ & 10.56 \\
\hline Threonine & $3 \cdot 79$ & 3.86 \\
\hline Serine & $5 \cdot 29$ & $5 \cdot 34$ \\
\hline Glutamic acid & $19 \cdot 07$ & $19 \cdot 95$ \\
\hline Proline & $4 \cdot 69$ & $4 \cdot 83$ \\
\hline Glycine & $4 \cdot 83$ & 5.05 \\
\hline Alanine & $6 \cdot 19$ & 6.60 \\
\hline Cystine & $2 \cdot 29$ & $2 \cdot 25$ \\
\hline Valine & $6 \cdot 42$ & 6.60 \\
\hline Methionine & $2 \cdot 95$ & $2 \cdot 87$ \\
\hline Isoleucine & $4 \cdot 51$ & $4 \cdot 82$ \\
\hline Leucine & $8 \cdot 34$ & 8.71 \\
\hline Tyrosine & 4.95 & $5 \cdot 21$ \\
\hline Phenylalanine & $5 \cdot 62$ & 5.99 \\
\hline Histidine & $2 \cdot 73$ & 285 \\
\hline Lysine (total) & $3 \cdot 91$ & 3.54 \\
\hline Lysine (reactive) & $99 \%$ & $98 \%$ \\
\hline Arginine & $8 \cdot 53$ & 8.72 \\
\hline
\end{tabular}

* Polarimetric method.

$\uparrow$ Modified method of Clegg (1956).

$\ddagger$ Lufl-Schoorl method.

$\S$ Lane and Eynon method (Ministry of Agriculture, Fisheries and Food, 1982).

tiers, each cage equipped with a feeder and a water bottle drinker. The experimental room was maintained at $22^{\circ}$, ambient humidity and with a $12 \mathrm{~h}$ light-dark cycle. Four groups of rats were fed on each diet in an incomplete randomized block design, with cages being allocated such that none of the diets was represented in the same tier more than once. The food intake, growth rate and efficiency of food utilization (EFU) of rats were recorded during 6 weeks of feeding. After 4 weeks, a nutrient digestibility study was carried out in which faeces were collected over a $7 \mathrm{~d}$ period and dried in a forced-draught oven at $60^{\circ}$ for $48 \mathrm{~h}$. Dry matter (DM) digestibility of diets was determined according to DM digestibility $=(\mathrm{DM}$ intake - faecal $\mathrm{DM}) / \mathrm{DM}$ intake. Gross energy values of diets and faeces were determined using a Parr adiabatic bomb calorimeter and $\mathrm{N}$ contents using a Tecator 
Table 2. Composition of the various grades of yellow rice

\begin{tabular}{|c|c|c|c|c|}
\hline Grades of yellow colour $(\mathrm{x}) \ldots$ & $\begin{array}{l}\text { Normal } \\
\text { white } \\
\text { rice } \\
(1)\end{array}$ & $\begin{array}{l}\text { Slightly } \\
\text { yellow } \\
\text { rice } \\
(2)\end{array}$ & $\begin{array}{l}\text { Moderately } \\
\text { yellow } \\
\text { rice } \\
(3)\end{array}$ & $\begin{array}{l}\text { Very yellow } \\
\text { (brownish) } \\
\text { rice } \\
\text { (4) }\end{array}$ \\
\hline Amount of rice ( $\mathrm{g} / \mathrm{kg}$ total rice) & 149 & $502 \cdot 0$ & 278 & 71 \\
\hline Moisture $(\mathrm{g} / \mathrm{kg})$ & $109 \cdot 7$ & $106 \cdot 1$ & $109 \cdot 9$ & $110 \cdot 0$ \\
\hline \multicolumn{5}{|l|}{ Crude protein (nitrogen $\times 6.25) *(y)$ : } \\
\hline Mean & $81 \cdot 4$ & $85 \cdot 8$ & $90 \cdot 8$ & 91.9 \\
\hline $\mathrm{SE}$ & 0.49 & 0.24 & 0.42 & $0 \cdot 36$ \\
\hline Total $\mathrm{N}(\mathrm{g} / \mathrm{kg} \mathrm{DM}) \dagger$ & $14 \cdot 62$ & $15 \cdot 36$ & $16 \cdot 32$ & $16 \cdot 52$ \\
\hline Non-protein $\mathrm{N}(\mathrm{g} / \mathrm{kg} \mathrm{DM}) \dagger$ & $0 \cdot 16$ & $0 \cdot 19$ & $0 \cdot 22$ & 0.45 \\
\hline Gross energy (MJ/kg DM) & $17 \cdot 80$ & $17 \cdot 85$ & $17 \cdot 80$ & $17 \cdot 73$ \\
\hline \multirow[t]{2}{*}{ Regression equation } & \multirow[t]{2}{*}{$r^{2}$} & \multicolumn{3}{|c|}{$\begin{array}{c}\text { Statistical significance }(P) \\
\text { of terms: }\end{array}$} \\
\hline & & $x^{2}$ & $x$ & Constant \\
\hline Linear: $y=3 \cdot 641 x+78 \cdot 408$ & $0 \cdot 91$ & 一 & 0.0001 & 0.0001 \\
\hline Quadratic: $y=-0.820 x^{2}+7.741 x+74.308$ & 0.95 & 0.0011 & 0.0001 & 0.0001 \\
\hline
\end{tabular}

* Six replicates.

$\uparrow$ Total and non-protein $\mathrm{N}$ contents of control white rice were 15.07 and $0.16 \mathrm{~g} / \mathrm{kg}$ DM respectively.

Kjeltec 1002 distilling unit and 1007 digester. The digestible energy (DE) and $\mathrm{N}$ contents of diets were calculated. At the end of the trial a general post-mortem examination was carried out and liver weights were recorded.

\section{Expt 2}

The four rice-based rat diets in Expt 1 contained less apparent metabolizable energy and lysine plus sulphur-containing amino acids than those recommended for broiler chicks (Bolton \& Blair, 1982); however, since use of nutrient concentrations that result in a submaximal growth rate generally enhances the detection of differences between entities being compared, the diets were fed to chicks.

Forty-eight 1-d-old, Ross-1 broiler cockerels, obtained from Ross Poultry UK Ltd, were housed in groups of three in cages that were arranged in four tiers. The room was provided with a $23 \mathrm{~h}$ light $-1 \mathrm{~h}$ dark cycle, and kept at ambient humidity. Room temperature was initially set at $32^{\circ}$ and then reduced by $0.5^{\circ} / \mathrm{d}$. Four groups of chicks were fed on each diet in a randomized block design that took into account the possible effects of tiers. Food intakes, body-weights and EFU of chicks were recorded during a $16 \mathrm{~d}$ feeding period. After $10 \mathrm{~d}$, a nutrient retention study was carried out in which excreta were collected over a $3 \mathrm{~d}$ period and analysed as in Expt 1. At the end of the feeding trial a general post-mortem examination was carried out and the weights of livers and pancreas were recorded.

\section{Expt 3}

White and yellow rice were included at $600 \mathrm{~g} / \mathrm{kg}$ in broiler chick diets of the same basal raw material composition (Table 4), thus allowing a direct comparison of the nutritive value of the two rice types. Sixty-four 1-d-old Ross-1 broiler cockerels were housed in groups of four, as in Expt 2, and fed on white and yellow rice-based diets in the mash form or as pellets. All methods were similar to those used in Expt 2. 
Table 3. Composition of the experimental diets ( $\mathrm{g} / \mathrm{kg}$ unless otherwise stated)

\begin{tabular}{|c|c|c|c|c|c|c|}
\hline & \multicolumn{4}{|c|}{ Expts 1 and 2} & \multirow{2}{*}{$\begin{array}{c}\text { Expt } 3 \\
\text { Basal }\end{array}$} & \\
\hline & \multicolumn{2}{|c|}{ White rice (WR) } & \multicolumn{2}{|c|}{ Yellow rice (YR) } & & \\
\hline \multicolumn{7}{|l|}{ Constituents } \\
\hline Rice & \multicolumn{2}{|c|}{$600 \cdot 00$} & \multicolumn{2}{|l|}{$600 \cdot 00$} & \multicolumn{2}{|l|}{$600 \cdot 00$} \\
\hline Fish meal & \multicolumn{2}{|c|}{$19 \cdot 18$} & \multicolumn{2}{|l|}{$17 \cdot 88$} & \multicolumn{2}{|l|}{$50 \cdot 00$} \\
\hline Meat-and-bone meal & \multicolumn{2}{|c|}{-} & \multicolumn{2}{|l|}{ - } & \multicolumn{2}{|l|}{$19 \cdot 85$} \\
\hline Soya-bean meal & \multicolumn{2}{|c|}{$246 \cdot 29$} & \multicolumn{2}{|l|}{$223 \cdot 90$} & \multicolumn{2}{|l|}{$233 \cdot 33$} \\
\hline Maize & \multicolumn{2}{|c|}{-} & \multirow{2}{*}{\multicolumn{2}{|c|}{$\begin{array}{r}6.18 \\
98.73\end{array}$}} & \multicolumn{2}{|l|}{$73 \cdot 78$} \\
\hline Sunflower meal & \multicolumn{2}{|c|}{$92 \cdot 11$} & & & \multicolumn{2}{|l|}{-} \\
\hline Dicalcium phosphate & \multicolumn{2}{|c|}{$25 \cdot 07$} & \multicolumn{2}{|l|}{$25 \cdot 48$} & \multicolumn{2}{|l|}{$16 \cdot 39$} \\
\hline Limestone & \multicolumn{2}{|c|}{$10 \cdot 17$} & \multicolumn{2}{|l|}{$10 \cdot 06$} & \multicolumn{2}{|l|}{ - } \\
\hline Salt & \multicolumn{2}{|c|}{3.43} & \multicolumn{2}{|l|}{$3 \cdot 44$} & \multicolumn{2}{|l|}{$2 \cdot 27$} \\
\hline Lysine & \multicolumn{2}{|c|}{$0 \cdot 75$} & $1 \cdot 33$ & & 1.58 & \\
\hline Vitamin-mineral-choline & & & 3.00 & & 3.00 & \\
\hline Proximate analyses of diets: & $\begin{array}{c}\text { White- } \\
\text { rice } \\
\text { mash }\end{array}$ & $\begin{array}{l}\text { Yellow- } \\
\text { rice } \\
\text { mash }\end{array}$ & $\begin{array}{l}\text { White- } \\
\text { rice } \\
\text { pellets }\end{array}$ & $\begin{array}{l}\text { Yellow- } \\
\text { rice } \\
\text { pellets }\end{array}$ & $\begin{array}{l}\text { Commercial } \\
\text { pellets }\end{array}$ & Basal \\
\hline Moisture & 109 & 105 & 116 & 120 & 105 & $104 \dagger$ \\
\hline Crude protein (nitrogen $\times 6.25$ ) & 193 & 216 & 199 & 187 & 222 & WR-203; YR-206 \\
\hline Crude fibre & 36 & 37 & 32 & 31 & 39 & $17.9+$ \\
\hline Crude fat & 12 & 12 & 12 & 8 & 42 & $17.6 t$ \\
\hline Ash & 54 & 65 & 79 & 58 & 57 & $55 \cdot 1+$ \\
\hline Calcium ${ }^{\dagger}$ & $12 \cdot 5$ & $12 \cdot 5$ & $12 \cdot 5$ & $12 \cdot 5$ & $12 \cdot 5$ & $10 \cdot 0$ \\
\hline Phosphorust & $7 \cdot 5$ & $7 \cdot 5$ & $7 \cdot 5$ & $7 \cdot 5$ & $7 \cdot 5$ & 6.9 \\
\hline Lysinet & $11 \cdot 6$ & $11 \cdot 6$ & $11 \cdot 6$ & $11 \cdot 6$ & $11 \cdot 6$ & $13 \cdot 0$ \\
\hline Methionine + cystine $\dagger$ & $7 \cdot 3$ & $7 \cdot 3$ & $7 \cdot 3$ & $7 \cdot 3$ & $7 \cdot 3$ & $7 \cdot 54$ \\
\hline Gross energy $(\mathrm{MJ} / \mathrm{kg} \mathrm{DM})$ & $17 \cdot 12$ & $17 \cdot 12$ & $17 \cdot 12$ & $17 \cdot 12$ & $18 \cdot 6$ & $18 \cdot 1$ \\
\hline $\mathrm{DE}$ rats $(\mathrm{MJ} / \mathrm{kg}) \dagger$ & $13 \cdot 5$ & $13 \cdot 5$ & $13 \cdot 5$ & $13 \cdot 5$ & $13 \cdot 5$ & -- \\
\hline $\mathrm{ME}$ chicks $(\mathrm{MJ} / \mathrm{kg}) \dagger$ & $11 \cdot 5$ & $11 \cdot 5$ & $11 \cdot 5$ & $11 \cdot 5$ & $11 \cdot 5$ & $13 \cdot 1$ \\
\hline
\end{tabular}

DM, dry matter; DE, digestible energy; ME, metabolizable energy.

* The vitamin premix provided the following nutrients $(\mathrm{mg} / \mathrm{kg}$ diet $)$ : retinol $3 \cdot 44$, cholecalciferol $62 \cdot 5, \alpha-$ tocopherol 10 , menadione $2 \cdot 0$, thiamin $0 \cdot 50$, riboflavin $6 \cdot 00$, nicotinic acid $2 \cdot 0 \mathrm{~g}$, pyridoxine $0 \cdot 1 \mathrm{~g}$, pantothenic acid $\mathrm{J} .0 \mathrm{~g}$, biotin 8 , folic acid $0.1 \mathrm{~g}$, cyanocobalamin 0.5 . Choline chloride was added at $1 \mathrm{~g} / \mathrm{kg}$. The mineral premix provided the following nutrients $(\mathrm{mg} / \mathrm{kg}$ diet $)$ : manganese 80.01 , zinc 60.00 , copper $0.5 \mathrm{~g}$, selenium 10 , iodine $0.1 \mathrm{~g}$. $\uparrow$ Calculated.

\section{Statistical analysis}

Rat and chick performance data were analysed by factorial analysis of variance, using SPSS (1988). Probabilities higher than $P=0.05$ were regarded as non-significant.

\section{RESULTS}

\section{Composition of the rice samples}

The crude protein content of the yellow rice was slightly higher than that of the white rice. Within the yellow-rice sample, $\mathrm{N}$ content of grains increased curvilinearly with degree of yellowing (quadratic relationship), the white fraction containing $81.4 \mathrm{~g}$ crude protein $/ \mathrm{kg}$ compared with $82.9 \mathrm{~g} / \mathrm{kg}$ for the control white-rice sample (Table 2); both samples had similar non-protein- $\mathrm{N}$ contents. Within the yellow-rice sample, non-protein- $\mathrm{N}$ increased 
Table 4. Expt 1. Performance of rats fed on rice-based diets of the same nutrient composition and a commercial control diet (6 weeks)*

\begin{tabular}{|c|c|c|c|c|c|c|c|c|}
\hline \multirow{2}{*}{ Diets... } & \multirow{2}{*}{$\begin{array}{l}\text { White- } \\
\text { rice } \\
\text { mash }\end{array}$} & \multirow{2}{*}{$\begin{array}{l}\text { Yellow- } \\
\text { rice } \\
\text { mash }\end{array}$} & \multirow{2}{*}{$\begin{array}{l}\text { White- } \\
\text { rice } \\
\text { pellets }\end{array}$} & \multirow{2}{*}{$\begin{array}{l}\text { Yellow- } \\
\text { rice } \\
\text { pellets }\end{array}$} & \multirow{2}{*}{$\begin{array}{l}\text { Commercial } \\
\text { rat } \\
\text { pellets }\end{array}$} & \multirow{2}{*}{$\begin{array}{l}\text { SE of } \\
\text { treatment } \\
\text { means }\end{array}$} & \multicolumn{2}{|c|}{$\begin{array}{c}\text { Statistical } \\
\text { significance }(P=) \\
\text { of main effects }\end{array}$} \\
\hline & & & & & & & $\begin{array}{l}\text { Diet } \\
\text { form } \dagger\end{array}$ & $\begin{array}{l}\text { Rice } \\
\text { type } \dagger\end{array}$ \\
\hline \multicolumn{9}{|l|}{ Growth performance } \\
\hline Initial body-wt (g) & $66 \cdot 4$ & $68 \cdot 2$ & $69 \cdot 6$ & $67 \cdot 5$ & $66 \cdot 0$ & 1.52 & - & - \\
\hline Wt gain $(\mathrm{g})$ & 256 & 252 & 296 & 283 & 282 & $10 \cdot 1$ & 0.007 & NS \\
\hline Food intake (g) & 829 & 819 & 965 & 957 & 952 & 26.9 & $0 \cdot 0001$ & NS \\
\hline $\begin{array}{l}\text { Efficiency of food } \\
\text { utilization }\end{array}$ & $0 \cdot 31$ & $0 \cdot 31$ & 0.31 & 0.29 & $0 \cdot 30$ & 0.006 & NS & NS \\
\hline \multicolumn{9}{|l|}{ Nutrient digestibility } \\
\hline $\begin{array}{l}\text { Dry matter (DM) } \\
\text { digestibility }\end{array}$ & $0 \cdot 87$ & 0.87 & $0 \cdot 84$ & 0.84 & 0.78 & 0.005 & 0.0001 & NS \\
\hline$N$ digestibility & 0.83 & 0.83 & $0 \cdot 82$ & $0 \cdot 82$ & 0.78 & 0005 & $0 \cdot 106$ & NS \\
\hline $\begin{array}{l}\text { Digestible energy } \\
(\mathrm{MJ} / \mathrm{kg} \mathrm{DM})\end{array}$ & $15 \cdot 26$ & 14.99 & $14 \cdot 62$ & $14 \cdot 50$ & $14 \cdot 67$ & 0.08 & $0 \cdot 0001$ & 0.030 \\
\hline $\begin{array}{l}\text { Excreta water content } \\
(\mathrm{g} / \mathrm{kg})\end{array}$ & 217 & 202 & 188 & 206 & 345 & $18 \cdot 2$ & NS & NS \\
\hline \multicolumn{9}{|l|}{ Organ wts } \\
\hline Body-wt $(\mathrm{g}) \S$ & 295 & 294 & 335 & 320 & 319 & $7 \cdot 5$ & - & - \\
\hline Liver wt $(\mathrm{g}) \S$ & $9 \cdot 01$ & $9 \cdot 61$ & $10 \cdot 46$ & $9 \cdot 91$ & 12.09 & 0.456 & NS & NS \\
\hline \multicolumn{9}{|c|}{$\begin{array}{l}\text { NS, not significant. } \\
\text { * For details of diets, see Table } 3 \text {. } \\
+ \text { The diet form by rice type interaction term was not significant in any variable. } \\
+ \text { Residual df for organ weights } 43 \text {, for other variables } 12 \text {. } \\
\$ \text { Liver weights were analysed with body-weight as covariate (statistical significance } P<0 \cdot 0001 \text {, diet } \\
<0.0001 \text { ). }\end{array}$} \\
\hline
\end{tabular}

with the yellowing of grains but this could only account for a fraction of the total increase in $\mathrm{N}$, indicating perhaps that the amino acids were higher in the yellow rice. The recovery of amino acids from rice, however, decreased as yellowing increased.

There were no major differences in starch, available starch, sugar, crude fibre, ash, calcium and phosphorus contents of the two rice types. The crude fat content of yellow rice was approximately half that of white rice, but since the values were less than $10 \mathrm{~g} / \mathrm{kg}$ its significance is unclear. Gross energy values of white and yellow rice were similar.

Lysine content, expressed relative to the crude protein, was $9.5 \%$ lower in yellow than in the white rice sample $(6.2 \%$ lower when expressed relative to the amount of rice). As yellowing increased, methionine, cystine, total and 'reactive' lysine, and arginine concentrations declined relative to the crude protein content (values not shown), but histidine content appeared to increase; however, relative to the amount of rice the only trends apparent were minor increases in the aspartic acid and arginine contents.

\section{Expt I}

The results are summarized in Table 4. No significant differences were apparent between the white- and yellow-rice-based diets in food intake, weight gain and EFU of rats, when the diet was presented in mash form or as pellets. However, pelleted diets produced a significantly higher food intake than mash diets, and rats consequently attained a higher 
Table 5. Expt 2. Performance of chicks fed on rice-based diets balanced for nutrients (16 days)*

\begin{tabular}{|c|c|c|c|c|c|c|c|c|}
\hline \multirow{2}{*}{ Diets... } & \multirow[b]{2}{*}{$\begin{array}{l}\text { White- } \\
\text { rice } \\
\text { mash }\end{array}$} & \multirow[b]{2}{*}{$\begin{array}{l}\text { Yellow- } \\
\text { rice } \\
\text { mash }\end{array}$} & \multirow[b]{2}{*}{$\begin{array}{l}\text { White- } \\
\text { rice } \\
\text { pellets }\end{array}$} & \multirow[b]{2}{*}{$\begin{array}{l}\text { Yellow- } \\
\text { rice } \\
\text { pellets }\end{array}$} & \multirow[b]{2}{*}{$\begin{array}{l}\text { SE of } \\
\text { treatment } \\
\text { means }\end{array}$} & \multicolumn{3}{|c|}{$\begin{array}{c}\text { Statistical significance }(P=) \\
\text { of main effects and } \\
\text { interactions }\end{array}$} \\
\hline & & & & & & $\begin{array}{l}\text { Diet } \\
\text { form }\end{array}$ & $\begin{array}{l}\text { Rice } \\
\text { type }\end{array}$ & $\begin{array}{l}\text { Diet form } x \\
\text { rice type }\end{array}$ \\
\hline \multicolumn{9}{|l|}{ Growth performance } \\
\hline Initial body-wt (g) & $38 \cdot 5$ & $38 \cdot 6$ & $38 \cdot 4$ & $38 \cdot 9$ & 0.03 & - & - & - \\
\hline Wt gain $(\mathrm{g})$ & 319 & 324 & 415 & 411 & $15 \cdot 3$ & 0.0001 & NS & NS \\
\hline Food intake (g) & 481 & 481 & 597 & 590 & $17 \cdot 1$ & $0 \cdot 0001$ & NS & NS \\
\hline $\begin{array}{l}\text { Efficiency of food } \\
\text { utilization }\end{array}$ & 0.66 & 0.67 & 0.69 & 0.70 & 0.016 & $0 \cdot 110$ & NS & NS \\
\hline \multicolumn{9}{|l|}{ Nutrient digestibility } \\
\hline $\begin{array}{l}\text { Dry matter (DM) } \\
\text { retention }\end{array}$ & 0.71 & 0.76 & 0.72 & 0.72 & $0 \cdot 012$ & NS & $0 \cdot 058$ & 0.111 \\
\hline Nitrogen retention & $0 \cdot 60$ & 0.64 & 0.61 & 0.61 & $0 \cdot 016$ & NS & NS & NS \\
\hline $\begin{array}{l}\text { Apparent metabolizable } \\
\text { energy }(\mathrm{MJ} / \mathrm{kg} \mathrm{DM})\end{array}$ & $12 \cdot 94$ & $13 \cdot 26$ & 13.69 & $12 \cdot 77$ & $0 \cdot 195$ & 0.083 & NS & NS \\
\hline $\begin{array}{l}\text { Excreta water content } \\
(\mathrm{g} / \mathrm{kg})\end{array}$ & 267 & 220 & 327 & 305 & $20 \cdot 0$ & $0 \cdot 04$ & $0 \cdot 113$ & NS \\
\hline \multicolumn{9}{|l|}{ Organ wts $\dagger_{+}^{+}$} \\
\hline Body-wt (g) & 331 & 329 & 416 & 407 & $13 \cdot 7$ & - & - & - \\
\hline Liver wt $(\mathrm{g})$ & $10 \cdot 14$ & $9 \cdot 56$ & $11 \cdot 65$ & $11 \cdot 60$ & $0 \cdot 463$ & NS & NS & NS \\
\hline Pancreas wt $(\mathrm{g})$ & $1 \cdot 09$ & $1 \cdot 24$ & $1 \cdot 15$ & $1 \cdot 19$ & $0 \cdot 006$ & 0.031 & 0.058 & NS \\
\hline
\end{tabular}

NS, not significant.

* For details of diets, see Table 3 .

$\dagger$ Residual df for organ weights 40 , for other variables 12 .

$\ddagger$ Organ weights were analysed with body-weight as covariate (statistical significance: $P<0.0001$ for liver weights and $P=0.027$ for pancreas weights).

growth rate; this was due to difficulty experienced by rats in holding and consuming the mash feed. EFU was unaffected by the diet form, and there were no significant interactions between rice type and diet form in any of these variables.

There were no significant differences between the white- and yellow-rice-based diets in $\mathrm{DM}$ and $\mathrm{N}$ digestibilities, but the DE of the yellow-rice-based diet was lower than that of the white-rice-based diet. Diet pelleting reduced DM and energy digestibility of both diets to about the same degree. The water contents of faeces were similar in all the rice-based diet groups.

The commercial diet produced a similar food intake, weight gain and EFU to those obtained with the pelleted rice-based diets; however, whilst it had the same DE as those for the rice-based diets, DM and $\mathrm{N}$ digestibilities were significantly lower $(P<0.05)$. The water content of faeces from the commercial-diet group was significantly higher than those from all other groups.

No mortality was recorded. Liver weights were unaffected by the type of rice or form of diet.

Expt 2

These results are summarized in Table 5. The food intake, weight gain and EFU of chicks fed on yellow-rice-based diets were not significantly different from those of chicks fed on the white-rice-based diets, and there were no significant interactions between rice type and 
Table 6. Expt 3. Performance of chicks fed on rice-based diets of the same basal raw material composition $(15 d)^{*}$

\begin{tabular}{|c|c|c|c|c|c|c|c|c|}
\hline \multirow{2}{*}{ Diets... } & \multirow[b]{2}{*}{$\begin{array}{l}\text { White- } \\
\text { rice } \\
\text { mash }\end{array}$} & \multirow[b]{2}{*}{$\begin{array}{l}\text { Yellow- } \\
\text { rice } \\
\text { mash }\end{array}$} & \multirow[b]{2}{*}{$\begin{array}{l}\text { White- } \\
\text { rice } \\
\text { pellets }\end{array}$} & \multirow[b]{2}{*}{$\begin{array}{l}\text { Yellow- } \\
\text { rice } \\
\text { pellets }\end{array}$} & \multirow[b]{2}{*}{$\begin{array}{c}\text { SE of } \\
\text { treatment } \\
\text { means }\end{array}$} & \multicolumn{3}{|c|}{$\begin{array}{c}\text { Statistical significance }(P=) \\
\text { of main effects and } \\
\text { interactions }\end{array}$} \\
\hline & & & & & & $\begin{array}{l}\text { Diet } \\
\text { form }\end{array}$ & $\begin{array}{l}\text { Rice } \\
\text { type }\end{array}$ & $\begin{array}{l}\text { Diet form } \times \\
\text { rice type }\end{array}$ \\
\hline \multicolumn{9}{|l|}{ Growth performance } \\
\hline Initial body wt $(\mathrm{g})$ & $38 \cdot 7$ & 38.9 & 38.6 & 38.9 & 0.27 & - & - & - \\
\hline Wt gain $(\mathrm{g})$ & 397 & 363 & 420 & 413 & 19.9 & 0.091 & NS & NS \\
\hline Food intake $(\mathrm{g})$ & 520 & 483 & 545 & 531 & $24 \cdot 1$ & $0 \cdot 159$ & $\mathrm{NS}$ & NS \\
\hline $\begin{array}{l}\text { Efficiency of food } \\
\text { utilization }\end{array}$ & 0.76 & $0-75$ & 0.77 & 0.78 & 0.010 & 0.082 & NS & NS \\
\hline \multicolumn{9}{|l|}{ Nutrient digestibility } \\
\hline $\begin{array}{l}\text { Dry matter (DM) } \\
\text { retention }\end{array}$ & 0.80 & 0.81 & 0.81 & 0.80 & 0.006 & NS & NS & NS \\
\hline Nitrogen retention & 0.66 & $0 \cdot 68$ & 0.67 & 0.66 & 0.010 & NS & NS & NS \\
\hline $\begin{array}{l}\text { Apparent metabolizable } \\
\text { energy }(\mathrm{MJ} / \mathrm{kg} \mathrm{DM})\end{array}$ & 14.91 & $15 \cdot 25$ & 15.09 & 14.97 & 0.099 & NS & NS & 0.038 \\
\hline $\begin{array}{l}\text { Excreta water content } \\
(\mathrm{g} / \mathrm{kg})\end{array}$ & 305 & 267 & 362 & 364 & $30 \cdot 6$ & 0.028 & NS & NS \\
\hline \multicolumn{9}{|l|}{ Organ wtst\$ } \\
\hline Body wt (g) & 430 & 400 & 448 & 441 & $12 \cdot 8$ & - & - & - \\
\hline Liver wt (g) & $14 \cdot 23$ & 13.09 & $15 \cdot 12$ & $14 \cdot 41$ & 0.627 & NS & NS & NS \\
\hline Pancreas wt (g) & $1 \cdot 41$ & $1 \cdot 38$ & $1 \cdot 39$ & $1 \cdot 29$ & 0.053 & 0.023 & NS & NS \\
\hline
\end{tabular}

NS, not significant.

* For details of diets, see Table 3 .

+ Residual df for organ weights 56 , and for other variables 12 .

Organ weights were analysed with body-wt as covariate (statistical significance: $P<0.0001$ for liver weights and $P=0.027$ for pancreas weights).

diet form in these variables. However, chicks fed on pelleted diets consumed significantly more food and attained a higher growth rate than those fed on mash diets. Over the $16 \mathrm{~d}$ experimental period EFU was slightly higher for the pellet than for mash diets; however, a closer examination of the data showed similar EFU for both forms of diets between 8 and $16 \mathrm{~d}$, indicating than an improvement in EFU of mash diets had taken place after the first week of age.

There were no significant effects of rice type or diet form on DM and $\mathrm{N}$ retentions, nor were there any significant interactions between rice type and diet form. Pelleting appeared to reduce the apparent metabolizable energy value of both rice-based diets. The water content of excreta from chicks fed on pelleted diets was significantly greater than those from chicks fed on mash diets.

No treatment-related mortality nor any effects on liver weight were recorded. Pancreas weights were significantly greater in mash diets than in pellet groups. There was a small effect ( $P=0.058$ ) of the rice type on pancreas weight, which was greater in the yellow-rice group.

$$
\text { Expt } 3
$$

These results are summarized in Table 6 . There were no significant effects of the rice type or diet form on the food intake, weight gain and EFU of chicks, although the values tended to be poorer for the mash diets. 
$\mathrm{DM}$ and $\mathrm{N}$ retentions were unaffected by the rice type or diet form. The apparent metabolizable energy values of yellow- and white-rice-based diets were similar, but there was an interaction between rice type and diet form indicating a greater detrimental effect of diet pelleting on yellow rice than on white rice. The water content of excreta was significantly higher in the pelleted groups than in the mash groups.

There was no treatment-related mortality. The type of rice fed had no significant effects on liver and pancreas weights; pancreas weights were, however, larger in mash than in the pellet groups.

\section{DISCUSSION}

The results of the present study indicate that yellowing of rice is associated with changes in nutrient composition, but a rice that is only moderately yellow will not produce any detrimental effects on growth when fed to rats and broiler chicks. The results further demonstrate that yellow rice can be included in broiler chick diets at $600 \mathrm{~g} / \mathrm{kg}$ without depressing the growth rate.

The main alteration in the nutrient composition of rice during yellowing was an increase in $\mathrm{N}$ content, only a small proportion of which was as non-protein- $\mathrm{N}$. The increase in crude protein could be associated with fungal activity on rough rice (Phillips et al. 1989). However, since much of the mycelium is likely to have been removed with the husk and bran layers during milling, and the milled rice was not examined for the presence of microorganisms, any suggestion of a relationship between protein content and the presence of fungi would be speculative.

The lowering in the concentration of lysine compared with a white-rice control as colour of grains within the yellow-rice sample became more yellow is in agreement with the findings of Eggum et al. (1984) who suggested that lysine decomposition is dependent on the temperature and duration of stack burning. In the present study, there were also decreases in the concentrations of 'reactive' lysine, methionine, cystine and arginine, relative to the crude protein content, as rice grains became more yellow, which could perhaps be indications of Maillard browning (Hurrell \& Carpenter, 1974). The small apparent increase in histidine observed may be associated with products of Maillard reaction that elute at the same time as histidine from the ion-exchange column (Plumb, 1989).

The feeding trials showed no significant differences between the white- and yellow-ricebased diets in their effects on rats and chicks; nor were there any consistent interactions to suggest that yellow rice was more prone than white rice to a lowering in nutritive value by the moist heat treatment of diet pelleting. Rat performances on the pelleted white- and yellow-rice-based diets were similar to that resulting from a commercial diet, and formulation of chick diets to contain the required apparent metabolizable energy (Expt 3) produced growth rates comparable with those obtained in other studies carried out under similar experimental conditions with a commercial-type diet of optimal nutrient specification (values not shown here). However, whilst the overall growth performance was unaffected, the DE of yellow rice in rats was slightly lower than that of the white rice, indicating a possible lowering in feeding value. This is in contrast to the findings of Eggum $e t$ al. (1984) that 'stack burning' of rice did not affect energy digestibility but decreased true protein digestibility and net protein utilization, which were lowered further in yellow rice than in white rice by heat treatment.

Since surplus rice and broken rice are used in non-ruminant livestock diets, it was of particular interest to study the utilization of the rice-based diets by young chicks. During the first week of Expt 2 EFU was lower in mash groups than in the pellet groups (not shown in Table 5) but EFU and DM retention between 10 and $13 \mathrm{~d}$ were similar, suggesting that 
1-d-old chicks can utilize mash diets containing whole rice grains after a few days of adaptation, which appears to involve pancreatic hypertrophy. However, the lower overall weight gain of chicks fed on mash was primarily due to their low food intake caused by poor feed texture, a problem that was overcome by diet pelleting. The smaller difference in food intake between mash and pelleted feed in Expt 3 may also be due to an improvement in feed texture by the additional fat in these diets compared with the diets of Expt 2 . The higher water content of excreta from chicks fed on pellets, compared with mash, is consistent with the suggestion of Marks (1981) that broiler chicks adjust their water intake to regulate food intake and EFU.

\section{REFERENCES}

Backoff, H. P. (1976). Some chemical changes in fish silage. Journal of Food Technology 11, 353-363.

Bolton, W. \& Blair, R. (1982). Ministry of Agriculture, Fisheries and Food Reference Book 174. Poultry Nutrition, p. 100. London: H.M. Stationery Office.

Clegg, K. M. (1956). The application of the anthrone reagent to the estimation of starch in cereals. Journal of the Science of Food and Agriculture 7, 40-44.

Eggum, B. O., Juliano, B. O., Villareal, C. P. \& Perez, C. M. (1984). Effect of treatment on composition and protein and energy utilization of rice and mung bean by rats. Qualitas Plantarum-Plant Foods for Human Nutrition 34, 261-272.

Gras, P. W., Banks, H. J., Bason, M. L. \& Esteves, L. A. (1989). A quantitative study of the influences of temperature, water activity, and storage atmosphere on the yellowing of milled rice. Journal of Cereal Science 9. 77-89.

Hurrell, R. F. \& Carpenter, K. J. (1974). Mechanisms of heat damage in proteins. 4. The reactive lysine content of heat damaged material as measured in different ways. British Journal of Nutrition 32, 589-603.

International Rice Research Institute (1983). Annual Report for 1981, pp. 21-24. Los Baños, Laguna, The Philippines: International Rice Research Institute.

Kinosita, R. \& Shikata, T. (1965). On toxic mouldy rice. In Mycotoxins in Foodstuffs, pp. 11]-132 [1. F. H. Purchase, editor]. Cambridge, Mass.: MIT Press.

Marks, H. L. (1981). Role of water in regulating feed intake and efficiency in broilers. Poultry Science 60, 698-707.

Ministry of Agriculture, Fisheries and Food (1982). The Feeding Stuffs (Sampling and Analysis) Regulations, 1982, Agriculture. Bulletin no. 1144. London: H.M. Stationery Office.

Ministry of Agriculture, Fisheries and Food (1986). The Analysis of Agricultural Materials. A manual of the analytical methods used by the Agricultural Development and Advisory Service. Reference Book 427. London: H.M. Stationery Office.

Moreau, C. (1979). Islanditoxicoses. In Moulds, Toxins and Food, pp. 190-196 [M. O. Moss, editor]. Chichester: Wiley.

Noland, P. R., Baugus, C. A. \& Johnson, Z. (1969). Using heat damaged rice in growing-finishing swine rations. Arkansas Farm Research 18, 12.

Phillips, S., Mitfa, R. \& Wallbridge, A. (1989). Rice yellowing during drying delays. Journal of Stored Products Research 25, 155-164.

Phillips, S., Widjaja, S., Wallbridge, A. \& Cooke, R. (1988). Rice yellowing during post-harvest drying by aeration and during storage. Journal of Stored Products Research 24, 173-181.

Plumb, V. E. (1989). Investigation of the effects of heat processing on proteins in the production of water stable fish feeds. MSc Thesis, Polytechnic of the South Bank, London.

Saito, M. (1959). Liver cirrhosis induced by metabolites of Penicillium islandicum Sopp. Acta Pathologica Japonica 9, 785-790.

SPSS (1988). SPSS/PC + V2O Base Manual for IBM PC/XT/AT and PS2. Chicago: SPSS Inc.

Van Der Wolk, P. C. (1913). Protascus colorans, a new genus and a new species of the Protoascineae-group, the source of yellow grains in rice. Mycological Central Bulletin 3, 153-157. 